物の単位翼量当りの property が $P$ となって, $M P=$ $M_{1} P_{1}+M_{2} P_{2}\left(M=M_{1}+M_{2}\right)$ を満足するもの方 Conserved property である。たとえば，酸素，炭酸ガス， 一酸化炭素の混合ガス中で然㹸する固体若素の場合に は輸送面を横切って輸送される物質は孷素で, Conserved property としては

$$
\begin{aligned}
& P_{0}=m_{\mathrm{o}_{2}}+\frac{32}{44} m_{\mathrm{co}_{2}}+\frac{16}{28} m_{\mathrm{co}}, \\
& P_{c}=\frac{12}{44} m_{\mathrm{co}_{2}}+\frac{12}{28} m_{\mathrm{co}}
\end{aligned}
$$

が採用される。

旡度美

格]

\subsubsection{4:536.24:2}

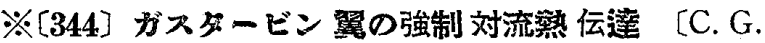
Wilson \& J.A. Pope, Inst. Mech. Engr., Proc., 1954, Vol. 168, No. 36, p. 861 876, 図 21, 表 1]

この論文はガスタービン翼の翼列実験と同時に強制 対流伝熱実験を行ったもので，翼面上の局所的熱伝達 率の分布と翼面上の压力分布ならびに境界層の状態と の関係について詳紬に調查検討を加えている，使用さ れた翼型は T 6 で入口角 $30^{\circ}$ ，出口角 $60^{\circ}$ の $50 \%$ 反動翼であり，流入角を $0 ， 25 ， 30 ， 35$ および $50^{\circ}$ に変え，流出速度と翼㹡長を用いたレイノルズ数を $1.8 \times 10^{5}$ ないし $7 \times 10^{5}$ に変化して行っている.一般 に局所的蓺伝達率は陂点で最大で, 翼の山面側では畦 点加ら後縁に宂って層流境界層の発達とともに低下す るが，流路ののど部付近で乱流境界層に遷移して熱伀 達率は念激に増大し，極大值をとって方ら乱流境界層 の発達とともに後縁に向って低下寸る. 翼の四面側で は，岐点のきわめて近くに乱流兴移点があり，翼の大 部分活乱流境界尿の状態にあり，蓺伝達率恔点付近 で一度急激に低下してから值ちに念激に增大し，極大 值をとってから後緣に问って低下する，なお翼全体の 平均熱伝達率と流入角抢よびレイノルズ数との関係に ついても諭じている.

战美

格]

\subsubsection{4}

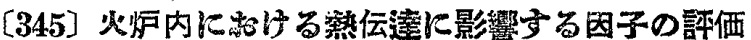

[M. Greyson, G.P. Mazie, J.W. Myers, R.C. Corey \& E.G. Graf, Combustion, 1956, Vol. 27, No. 8, p. 34〜39, 図 7, 表 1] 石炭燃接装置にお ける熱吸収效率を整理しようとする研究は多年にわた って行われているが，いまだ完壁の域に達していな い.このような整理を行う場合の图難の一つは正確な 火炉データが久除していることである. 本論文は 1948 〜1953 年にわたって, U. S. Bureau of Mines が五 つの工業用ボイラ火炉について行った，信賴虔の高い 火炉デー夕を Broido, Hudson-Orrok, 修正 HudsonOrrok, Wohlenberg 㘧よび Hurvich の整理法によ って統計学を応用して整理しようとする試みについて のべたものである．以上の王つの整理法の奏験結果と の一致の度合おょびその適用範国を表にして示してい る. 最後に著者は正確な整理法を見出すためには，ま ず火炎温度, 火炎体積, スラグや灰分で扔抒われたボ イラ管壁の放射率および温度についての知識を明確に する必要があることをのべ，すべての将来の研究が实 験デー夕を統計的に解䐆し，測定精度の推定を行いう るように計画されることを推奖している。【西川兼康】

\subsubsection{1}

†[346]サーモサイホン・リボイラに対する設訪デー

3 [D.C. Lee, J.W. Dorsey, G.Z. Moore \& F.D. Mayfield, Chem. Engg. Progress, 1956, Vol. 52, No. 4, p. 160 164, 図 8, 㳖 1] 怔

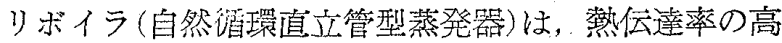
いこと，必要な空閒の小さいこと，および管が污損し た場合に被除汃签易であること等のために化学工場で 多年使用されている.しかしサーモサイホン・リボイ ラに効する従来発表された熱伝達率および最高許容熱 責荷のデータは設計に利用するには不満足である，著 者はこのようなデーー多得るために外径 1 in，長さ 10 $\mathrm{ft}$ の 7 本のアドミラリテー管よりなる小形のリボイラ について笑験し，熱通過係数および最高許容熱售荷を 物性值の異なる数㯖の液体（水， $\mathrm{n}$-プロパノール，ア セトン，プロピレン・グリコール，エチル・トルエン， ベンゼン，nーブタン）について，いろいろな方和 いて求めている。功 $2500 \mathrm{Btu} / \mathrm{h} \mathrm{ft}{ }^{2 \circ} \mathrm{F}$ の熱通過 係数抢よび $100000 \mathrm{Btu} / \mathrm{h} \mathrm{ft}{ }^{2}$ の最高熱急荷が $127 \mathrm{lb} /$ in $^{2}$ の圧力に拈ける水について, 一方 $200 \mathrm{Btu} / \mathrm{h} \mathrm{ft} \mathrm{ft}^{2 \circ} \mathrm{F}$ 以下の熱通過係数が $2 \mathrm{lb} / \mathrm{in}^{2}$ のエチル・トルエンにつ いてえられ，他の液体はこれらの中間の值を示した。 著者はこれらの最高熱負荷のデー夕を䵩次元表示で1 本の曲線にまとめて园示し，また空䒝門そくや脈動流 について観察し，リボイラの最高賁荷をうるための適 切な運転力法を提桑している. 最後に Celanese 会社 のリボイラの基準設訪㳖にして赤してある.

\section{[西川 兼康]}

\section{$536.21: 539.217$}

〔347]湿り录孔性物質に和ける伝熱 「O. Krischer u. H. Esdorn, Forschung, 1956, Bd. 22, Nr. 1, s. 1

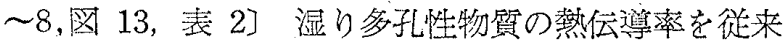
の方法で正確に测定することは非常に困難である。そ れは温度こう配が存在すると，空気荒澫している気 孔内で蒸気搪政が起るからである。したがって良来の 方法で求めた湿り物体の蓺伝導率の值は低温において のみ信頼できるにすぎないしかるに著者がさきに発 表した熱伝導摔の简易じん速測定法（日本機械学会誌 第59巻第445号, 161 ページに据録)によれば, 測定所要 時間も短く, 温度こう配も小さくできるので, 高温 $(90$ ${ }^{\circ} \mathrm{C}$ ま゙)においても湿り物体の正確な熱伝導率の值を 求めること功でさる，本論交はこの方法を用いて湿り 多孔性物質の熱伝導率を測定し，その場合の伝熱機構 についてのベなものである。まず 3 種の異なる靔造用 材料について熱伝導率と温度および湿り度との関係を 実験的に求め，その結果を簡単な構造模型を仮定して 訪明している。多孔性の物質は伝熱に関しては熱流の 方向に直列に配琵された平板群と並列に配置された平 板群との組合せよりなる構造と考えることができる。 湿り多孔性物貸の場合には伀熱層の種類としては，(i) 固体内の熟伝導，（ii）液体内の熱伝導，（iii）気孔隔壁 の湿った部分による蒸気拡散を伴う空氛中の熱伝導，

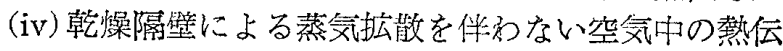

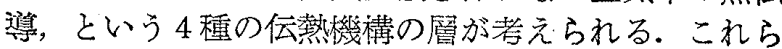
の各屬の割合と気孔率むょび湿り度との関係を求めて おけば，熱伝導率を計算によって求めることができる。 